\title{
Do Distance Education students owned their learning? Students' perceptions of parenting styles and sex role ideologies
}

\author{
Samuel Asare Amoah \\ Psychology and Education, Department, \\ University of Education, Winneba \\ Francis Owusu-Mensah \\ Institute of Distance and e-learning, \\ University of Education, Winneba \\ Abena Gyamera \\ Municipal Education Office, \\ Ghana Education Service, Koforidua \\ Ankama Gideon Mensah \\ Psychology and Education, Department, \\ University of Education, Winneba
}

\begin{abstract}
Students have different ideologies about what they consider appropriate and inappropriate when it comes to learning. In view of this the study sought to find out if DE students own their learning regarding parenting styles and sex role ideologies. Correlational research design was employed in this study. Stratified and simple random sampling techniques were used to select 300 participants from a population of 1480. Using an adopted instruments the Pearson-Product Moment Correlation was used to establish association between parenting styles and sex role ideology and regression was used to ascertain the predictions of the variables. It was found that parenting styles do not contribute to sex role ideologies of the participants to foster learning. However, individuals with authoritative parenting style were more likely to form more modern sex role ideology which influences their learning episode, and individuals with authoritarian parenting style were more likely to have more traditional sex role ideology. The study recommends that since parenting styles relates with sex role ideology DE students need to be guided on how they learn through guidance and counselling to develop the best ideology to learning. Again cultural sentiment need to guide DE students who come from varied cultural settings.
\end{abstract}

Key words: Parenting Styles, Sex role ideology, Distance Education students

\section{INTRODUCTION}

Parents all over the world have different ideologies about what they consider appropriate and inappropriate when it comes to parenting their children. It focuses on how they act and react to their children it involves beliefs and values in how children are nurtured (Cherry, 2010).

Researchers have covered convincingly links between parenting styles and how they influence children behaviours, altitudes, cognitions, beliefs and developments towards learning. For instance, studies by Cherry (2010), Darling (2001), Dornbusch, Ritter, Leiderman and Roberts (1987), Steinberg, Elman and Mounts (1989) have all shown correlations between parenting styles and children academic performance, competence, self-esteem etc. 
Sex role ideologies has also being found to relate to parenting styles. One of such theories is the social role theory which suggests that almost all behavioural differences between males and females are the result of cultural stereotypes about gender and the resulting social roles that are taught to young people that emanate from parenting styles (Hyde, 1993).

Another explanation that has been given to sex-role development is found in a cognitive development theory proposed by Lawrence Kohlberg. It was based on the view that children play an active role in the reinforcement of appropriate sex roles which informs how individuals develop better understanding about themselves through learning underpin by parenting styles. Once children become aware of their gender label, they come to value behaviours, objects, and attitudes associated with their gender. Each child becomes highly motivated to learn and own what learnt about how members of his or her own sex/gender act and then behaves in the way that is considered appropriate for that gender and such dwells on parenting styles. This thus, suggest how children/learners learn especially distance education (DE) students.

\section{How do distance Education Students (DE) learn?}

Distance education students learning in the university are sometimes classified as voluntary learners (Owusu-Mensah, 2018). Further, except during face-to-face contacts, tutorials most do not have lecture theatres, and lecture rooms all influence DE students' learning. Reading on one's own is not easy, hence for effective learning numerous strategies need to be adopted by the DE learner. Different learning styles, support services both outside and in-text, belief of the learner and a host of others are what the DE student need to encounter to bring about effective learning and how to own such learning.

The DE student, just like any other learner, should own his/her learning for life or to be functional rather than learning in school. Such a student should ask complex questions, seek relationship between topics, ideas, and use analogies (Amoah, 2011) which DE students do. Further, the student should develop and use temporary pegs on which they understand ideas theories and concepts and assimilate them into their intellectual framework (Hounsele, 1979) and these are informed by the ideological standpoint as well as how the individual was trained. Such individual therefore need to know him/herself to be able to self-directed, and be able to have rich review of experiences that can serve as a resource of learning (Owusu-Mensah, 2018).

\section{Our Research interest}

Parenting styles play a key role in the overall development of children be it social or education (Owano, 2010). Globally, the association of parenting styles and sex role ideologies has been consistent from one culture to another. Studies by Kopko (2007); Chao (2000); Keller and Otto (2009) have all shown that cultures that espouse authoritative parenting style endorse modern and traditional sex role ideology. This reinforces and provide evidence as to how learners own their learning.

Akotia and Anum (2012) opined that this situation is not very different from what pertains in Ghana. The problem however is, should there be a separate role for males and females in our society and how will such separation inform the way that they learn?. Studies have shown that problems of sex roles are very common in cultures that espouse traditional sex role ideology than those cultures that espouse modern sex role ideology (Etchezahar \& Ungaretti, 2013).

The gradual paradigm shift and the problems associated with sex roles are not exclusive to Ghanaian society; the Ghanaian society traditionally has prescriptions for the appropriate male and female roles (Ampofo, 2001). These stereotyping have moved into our schools and every 
aspect of our society and influence how learners learn and own what they learn. Each of these sexes then learn differently and own what they learn. These transcends to the distance education culture where role assignment influence and shape how they learn hence our interest and the lens of analysis is to analyse the breadth and depth on how parenting styles of the participants and their beliefs/perception of the appropriate roles support them own what they learn.

\section{Purpose of the Study}

The study sought to assess the three components: the correlation between parenting styles used to train students and their developed sex role ideologies, and the way the roles influence how they study as well as how DE students own what they learn.

\section{Objectives of the Study}

The objectives is a three component model for students to own their learning. It stresses that it is not only establishing;

1. the relationship between parenting styles and sex role ideologies of DE students but also how

2. parenting styles predict the sex role ideologies of DE students of UEW DE centres in an enabling environment, through a comprehensive multifaceted and cohesive approach to support learners own their learning.

\section{Research Hypotheses}

The following research hypotheses guided the study:

1. There will be a statistically significant correlation between authoritative parenting style and modern sex role ideology of DE students.

2. There will be a statistically significant correlation between authoritative parenting style and traditional sex role ideology of DE students of UEW.

\section{Research Question}

What extent does parenting styles, sex role ideologies support DE students learn to own their learning?

\section{Significance of the Study}

Finding from the study will support DE students to identify their learning strategies. It will further help researchers know the integration of parenting styles verses sex role ideology in supporting students own their learning and the barriers of owning learning thereof.

\section{Limitations of the Study}

The first limitation of this study was that findings could only be generalised to DE students within the selected centres. Centres outside this population may not have similar characteristics as the targeted population and therefore findings of this study cannot be generalized outside the population of this study.

\section{Delimitation of the Study}

The study was delimited to two centres of UEW with a sample of $300 \mathrm{DE}$ students from Wonneba and Techiman. The study was also delimited to the relationship between the students' perception of parenting styles and sex role ideology.

\section{Parenting Styles}

\section{LITERATURE UPTAKE}

Parenting styles have been explained variously. These include parenting as purposive activities aimed at ensuring survival and development of children (Hughughi and Long, 2004); various 
parenting activities aimed at promoting children's welfare such as physical care, emotional care and social care (Hoffman, 2000.

Most of the popular ideas about parenting style were drawn from the work of Diana Baumrind (Dewar, 2010). As a psychologist, Baumrind was very interested in the various ways parents attempt to socialize their children. According to Dewar (2010), Baumrind noted that the very idea of parental control had fallen into disrepute and she asserted that may be because people were equating "control" with blind obedience, harsh punishment, and domineering manipulative behaviour (Baumrind, 1966 cited by Dewar, 2010).

In addition to three are (3) main types of parenting styles; the Authoritative, the Authoritarian and the Permissive, further studies have also come out with the fourth type of parenting style which is the Uninvolved/Neglecting/Indulgent parenting (Dewar, 2010). Each of these support research and how learners learn. In relation to this, many studies exist that examined parenting styles (e.g., Abell, Clawson, Washington, Bost, \& Vaughn, 1996; Beyer, 1995; Bluestone \& Tamis-LeMonda, 1999) have all studied parenting style. Baumrind's parenting styles of authoritarian is often used in studies investigating parenting styles in relation to diverse child outcome variables, such as academic achievement, (Dornbusch et al., 1987; Hart, Nelson, Robinson, Olsen, \& McNeilly-Choque, 1998; Hill, 1995; Lamborn, Mounts, Steinberg \& Dornbusch, 1991; Shumow, Vandell, \& Posner, 1998).

Studies that examined how parenting styles influenced the cognitive development of young elementary-aged children are rare (e.g., Chen, Dong, \& Zhou, 1997). Dornbusch et al. (1987) found that authoritarian and permissive parenting styles were negatively associated with higher grades, whereas the authoritative parenting style was positively associated with higher grades. Radziszewska, Richardson, Dent, and Flay (1996) found similar results in their study of 15-year-olds. In another study of adolescents, Leung, Lau, and Lam (1998) found that academic achievement was negatively related to authoritarianism. In a study of adolescent minority students (Hispanic American, African American, and Asian American), however, Boveja (1998) found that adolescents who perceived their parents to be authoritative engaged in more effective learning and studying strategies.

Supporting this argument Kopko (2007), asserts that parenting styles influence children either positively or negatively children's behaviours. For instance whereas a cooperative, motivated, and responsible teen may be more likely to have parents who exercise an authoritative parenting style; an uncooperative, immature, and irresponsible teen may be more likely to elicit a parenting style that is authoritarian or uninvolved. Parenting style has also been found to predict children well-being in the domains of social competence, psychological development, academic performance, and cognition.

Greenwood (2014) asserts that the authoritative parenting style is considered the "ideal" parenting style and produces children with high level of self-reliance and self-esteem, who are socially responsible, independent and achievement oriented to add who will learn and own it. In conclusion parenting styles tends to influence learners learning capacity.

\section{Sex Role Ideology}

The assumption of being a man or a woman was based on biological and natural facts in history (Arnold, 2010). However, this assumption has given way to the concept of gender which considers that cultural influences, socialization processes and psychological features are key factors that influence the fact of being men or women (Etchezahar \& Ungaretti, 2013). 
Consequently, it becomes important how culture interweaves beliefs related to the roles that men and women play in society (Etchezahar \& Ungaretti, 2013).

In this particular study, sex role ideology is explained as a set of attributes, including attitudes, personality traits and behaviours, that a culture defines as appropriate for each sex. These beliefs are generally held, at least to some extent, by a majority of the culture's members.

In support, sex role ideology refers to the attitudes regarding the appropriate roles, rights and responsibilities of men and women in society (Kroska, 2014); individuals beliefs about the ways in which individuals, families, communities and societal roles are defined by gender (Slavkin and Stright, 2000); attitudes towards men and women's role in society have been referred to as gender/sex role ideology or perception (Hochschild, 1989; Akotia and Anum, 2012), reflection in the domains such as caregiving, nurturing, homemaking, breadwinning, discipline and parenting (Kroska, 2014). These activities are categorised into either traditional or modern/egalitarian sex role ideologies. In contrast, the traditional sex role ideology according to Kroska (2014) believes in distinctions between the roles of men and women in our societies and homes. According to him the traditional sex role ideology about a family for instance is when men fulfil their family roles through discipline and instrumental breadwinning activities and women fulfil their roles through nurturing, homemaker, and parenting activities.

As a comparison, Akotia and Anum (2012) asserts that individuals who hold traditional sex role ideology believe that men's and women's spheres of work are different such that men's sphere is 'paid work' while women's sphere is home. With the traditional sex role ideology, women are seen to be weak, cooperative, submissive, accommodating, avoiding and nurturing while men should be strong, aggressive, powerful, competitive and dominant (Maslak \& Singhal, 2008). Men on the other hand hold power and decision-making, and women are oriented mainly toward the family and put the family's interests above their own (Maslak \& Singhal, 2008). Hence, the traditional sex role ideology is one that suggests women and men should have different roles.

In the case of modern sex role ideology, it discards the idea that there are distinctions between male and female roles and believes in gender equality and flexibility with regards to appropriate roles and responsibilities (Barry \& Beitel, 2006; Akotia \& Anum, 2012). The modern sex role ideology maintains that power and roles are distributed equally between men and women and that women are identified equally in the same spheres as men (Barry \& Beitel, 2006; Hochschild, 1989; Akotia \& Anum, 2012). Kroska (2014) by contrasting the modern sex role ideology with the traditional sex role ideology identified modern sex role as an ideology which endorses and values men and women equal, and share all activities and responsibilities within a family. These shared activities include caregiving, discipline, breadwinning, nurturing and homemaking.

Relatively in research, Opia, (2010) has established that one of the strongest influences on a person's perceived sex role ideology is his or her parents. Parents are our teachers not only of such basic skills as talking and walking, but also of attitudes, beliefs and behaviours. In Opia's study some of the parents still hold the traditional belief of maleness and femaleness and the kind of activities they disseminate whilst others hold the egalitarian ideology of gender equality in roles and responsibilities (Opia, 2010), hence both operate unequal level especially in learning. 


\section{Parenting styles, sex role ideologies and owning of learning by students}

Individuals' belief about learning in any learning environment is crucial and tends to depend on the individuals perspectives. DE students' learning is moulded around learning being thematic and not 'taken-for-granted' since learners are more aware of themselves and more aware of the context (Ankama, 2017; Hounsele, 1979). Being more aware of one's self is influenced by the parenting styles (Ankama, 2017), it ensures that for real learning to happen the learner should be curious to distinguish between learning and understanding so that he/she can develop perspectives, a point of view and adopt general principles which later can be applied to specific situation and issues (Hounsele, 1979), which dovetails into the identified sex role (Anklama, 2017).

Researches have shown that, to own learning, students are in the categories of 'syllabus dependent' those who rely solely on syllabus to learn, 'syllabus autonomous'-those who prefer having the freedom to study the way they want(authoritative learners), 'cue-seeking' -those who are strategies but narrow in their learning, 'cue-deaf' rely on what is learnt, 'deep-level'develop better understanding to own learning (Hounsele, 1979); effective learning styles, support services-both outside and in-text, sign-posting in modules and peer grouping and collaborative learning (Owusu-Mensah, 2018), effective relationship between parenting styles and sex role ideologies to support the owning of learning (Ankama, 2017). All these studies are about student learning, however, this study focuses on how DE students own their learning having in mind their parenting styles as well as sex role ideologies. Whatever the situations, theories inform how the relationship are established.

\section{THEORETICAL FRAMEWORK}

This study was guided by three theories namely; Baumrind's Parenting styles theory, Albert Bandura's Social Cognitive theory, Gender Role Socialisation theory and Social Role Theory. Inferences were drawn from these theories to form the theoretical base of this study. Even though the theories did not specifically talk about the variables in this study, there have been some evidences which suggest that these theories were useful resources to support the framework of the study.

The parenting styles theory is based on two dimensions: demandingness and responsiveness. The theory posits that all the parenting styles run the gamut of high or low in demandingness and responsiveness, or moderating the two depending on a parent's position on parenting. According to Ribeiro (2009), Baumrind grouped parents' behaviour according to whether they were high or low on parental demandingness or responsiveness and created a typology of three parenting styles: authoritative, authoritarian, and permissive parenting styles.

Bandura's Social Cognitive Theory emphasises learning through observation of others behaviour. Modelling and imitating behaviour of others is an important tenant in this contextual theory. The Social Cognitive Theory (SCT) offers understanding of children's learning skills through experiences to which they are exposed. Bandura (2002) believe children are active and interactive members in their learning processes. Modelling and reinforcement are primary processes that have been invoked to explain the development of self. Bandura further, stated that children encounter interaction on a daily basis and use them in similar future situations whiles owning what they learn. In conclusion, inferences are drawn from Bandura's theory that there is a simple linear cause and effect relation in parents' style of training their children and the perception or ideology formed by the children with regard to the appropriate roles for men and women. 
The gender role socialization theory on the other hand, posits that different people and objects in the child's environment provide rewards and models that shape behaviour to fit gender role norms in a particular society (Helgeson, 2009; cited by Akotia \& Anum, 2012). Every society prescribes appropriate roles for females and males with varying sanctions for those who deviate from these norms (Ampofo, 2001). These norms are inculcated through socialisation and are imbibed by the individual from early childhood.

In the Ghanaian society, like other African communities, has prescriptions for appropriate male and female roles (Ampofo, 2001). The cultural construction of masculinity and femininity in Ghanaian society includes a belief in fundamental biological distinctions between male and female human nature and corresponding behavioural prescriptions (Akotia \& Anum, 2012). These are usually expressed in community norms and values and are often used to maintain social control over women and children (Akotia \& Anum, 2012; Nukunya, 2003). Children thus, own what they learn through socialisation.

Social role theory also liken the gender role socialisation theory and recognises the historical division in roles and responsibility between women; who often assumed responsibilities at home, and men; who often assumed responsibilities outside the home (Eagly, 1987; Moss, 2008). As a consequence of the concomitant sex differences in social behaviour, the expectancies of men and women began to diverge (Eagly, 1987). These expectancies are transmitted to future generations and, in turn, impinge on the social behaviour of each gender (Eagly, 1997; Eagly, Wood, \& Diekman, 2000) and represent sexual stereotypes (Williams \& Best, 1982). Accordingly, the behaviour of men and women is governed by the stereotypes of their social roles (Moss 2008).

\section{Conceptual Framework}

This study was conceived based on the relationship between the perception of the students about parenting styles as independent variables and their perceived ideologies (sex role ideologies) and how these influence how they learn as the dependent variables.

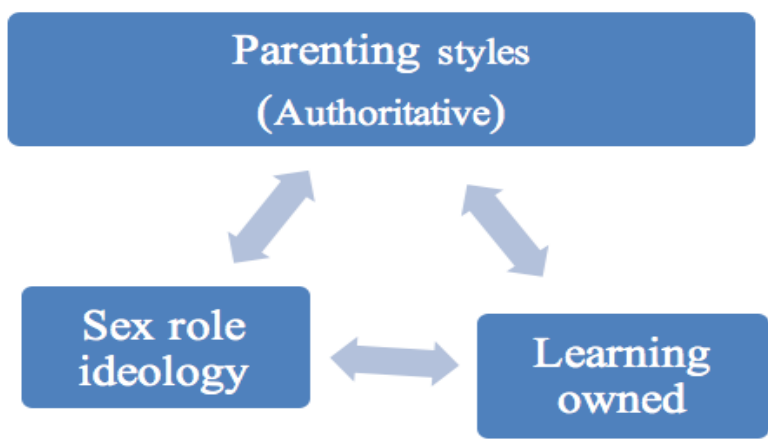

Figure 1: Conceptual Framework

Figure 1 present the conceptual framework for the study. It is about establishing the relationship between the three variable depicting the three component. Itn establishes how parenting stlye ;link up with sex role ideologies and leaner owned learning. It is cyclical since each of the components can be used to start with interactions.

In a null shell, figure 1 above represents a pictorial representation of what this study is all about. 


\section{Research Design}

\section{RESEARCH METHODOLOGY}

To measure the relationship between parenting styles and sex role ideologies of students, correlational research design was employed in this study. Correlational design is a quantitative research design which allows researchers to establish the relationship between variables.

With the analysis lens of establishing the relationship between parenting styles and sex role ideologies and how learners own their learning, the correlation design was deemed appropriate for this study because it allows the researcher to establish the relationship between the variables under study, determine the direction of the relationship and also make predictions about the variable under study.

\section{Population of the Study}

A research population according to Kusi (2012) is a group of individuals or people with the same characteristics and in whom the researcher is interested. It may also be defined as a group the researcher generalised his or her research findings to. In this study the targeted population was DE students of Techiman, and Winneba. With a population of 1480 students. Details of the population are provided in Table 1.

Table 1. Population of Selected DE centres

\begin{tabular}{llll}
\hline Centre & Males(Authoritative) & $\begin{array}{l}\text { Females } \\
\text { (Authoritative) }\end{array}$ & $\begin{array}{l}\text { Total } \\
\text { (Authoritative) }\end{array}$ \\
\hline Techiman & 5200 & 450() & $\mathbf{9 7 0 ( )}$ \\
Winneba & 2780 & 2320 & $\mathbf{5 1 0 0}$ \\
\hline Total & 798 & 682 & $\mathbf{1 4 8 0}$ \\
\hline
\end{tabular}

Source: Pru District Education Statistics (2015, March) N = 1480

\section{Sample Size}

Krejcie and Morgan's (1970) guideline for calculating sample size for a study, a sample of 300 was deemed appropriate for the study out of 1480 . Out of the sample of 300, 195 students were selected from Winneba centre and 105 students were selected from Techiman centre.

\section{Sampling Technique}

Participants of this study were selected using stratified, purposive and simple random sampling techniques. Due to the diverse characteristics and the stratified nature of the population, stratified probability sampling technique was firstly used followed with the purposive and simple random techniques. In all a total sample of 300 respondents were selected firstly by stratified sampling and simple random selection.

\section{Instrument}

The measuring instruments used in this study were in three sections. The first section contained instruments measuring parenting styles and the second section also contained instruments measuring participants' gender role ideologies. Parenting style of the participants was measured with Buri's (1991) Parental Authority Questionnaire (PAQ) which was adapted after pilot test.

The The sex role ideology was measured with Sex Role Ideology Scale (SRIS) developed by Williams and Best (1990). The scale originally had 30 items in the instrument which measures prescribe behaviours and responsibilities of men and women. However, since the original instrument was used in cultures different from the background of the population of this study, the instruments were piloted and 28 items were adapted. Factor analysis formed the validating 
statistical instrument used. Views on how they own their learning, the third section, were measured with additional items in the instrument.

\section{Data Collection Procedure}

Participation in this study was voluntary and anonymous. For the selection of respondents from the two centres, the coordinators of the centres involved in this study were served with an introductory letter indicating the purpose of the study. After approval was given, the researchers arranged for the data collection. Participants were selected based on the sampling technique for the study after participants had given their consent.

\section{Validity of the instrument}

The two instruments adapted - Parental Authority Questionnaire (PAQ) designed by Buri (1991) and Sex Role Ideology Scale (SRIS) developed by Williams and Best (1990) - were developed to cover the content of both parenting styles and sex role ideologies respectively. Hence both content and construct validity of the instruments used in the study were well ascertained. The third aspect of the learners expectation of owing their learning were validated using the conbach alpha.

\section{Reliability of the measuring instruments}

The reliability of the instruments was estimated after the pilot study using the Cronbach's reliability coefficient, which is a measure of internal consistency. According to Frankel \& Wallen (2002), 0.7 Cronbach alpha is the appropriate threshold to ascertain the reliability of any measuring instrument. A reliability of 0.78 was obtained for parenting style constructs and 0.71 was obtained for sex role ideology constructs after pilot studies.

\section{Data Analysis}

The data were analysed using both descriptive and inferential statistics. Descriptive statistics involved calculating frequencies, means, and percentages. The purpose of inferential statistics enabled the researcher to generalise the results from the sample to the population. Since this was a correlational study, Pearson-Product Moment Correlation (Pearson r') was used to measure the relationship between the variables at .05 levels of significant. However, regression analysis was conducted to measure the predictions and contributions of the variables at (0.05) significance levels, and 0.81 for learner's perception of owing their learning.

\section{Ethical Considerations}

Ethical consideration is one of the important elements that cannot be undermined in every educational research. According to Kusi (2012), they are those issues that are related to how the educational researchers conduct themselves or their practices and the consequences of such practices on the people who participate in their research. The way ethical issues are addressed in a research study can affect the validity and trustworthiness of the research outcome. However bearing in mind the importance of these issues, the researcher put in place considerations of the following ethical issues; consent, confidentiality and anonymity.

\section{Analyses of Hypotheses and research question}

Pearson correlation was used to test for the hypotheses 1 and 2 as well as the research question generated. The correlations among the variables in this study were presented in the Table 5. at $\mathrm{p}<.05$ level of significance. Parenting styles-authoritative and sex role ideologies (modern and traditional sex role ideologies), owing learning were grouped according to each construct and transformed into single units which allowed for correlation analysis on the 
variables. This special coding allowed the variables to be classified as one unit or a single variable.

Table 5: Correlation Coefficient of parenting style, sex role ideologies and owning of learning

\begin{tabular}{lllll} 
& APS & OWL & TSRI & MSRI \\
APS & - & $.670^{*}$ & .088 & $.169^{*}$ \\
OWL & $.670^{*}$ & - & $.165^{*}$ & .085 \\
TSRI & .088 & $.165^{*}$ & - & .003 \\
MSRI & $.169^{*}$ & .085 & .003 & - \\
\multicolumn{5}{c}{ Source: Fieldwork data (2017) }
\end{tabular}

Table 5 show Pearson correlation coefficient values and the asterisk against each coefficient show the level of significance; one or single $\left(^{*}\right.$ ) asterisk means that the Pearson ' $r$ ' was obtained at $(\mathrm{p}<.05)$ significant level and double $\left(^{*}\right)$ asterisks means the Pearson ' $r$ ' was obtained at $(\mathrm{p}<.05)$ significant level.

In testing for hypothesis 1, Table 5 shows a significant positive relationship between Authoritative parenting style (APS) and Modern Sex Role ideology(MSRI) $(r=.169, p<.05)$. This hypothesis 'there will be statistically significant correlation between authoritative parenting style and modern sex role ideology'. On the other hand, there was no significant relationship between Authoritative parenting style (APS) and traditional sex role ideology at ( $\mathrm{r}$ $=.088, \mathrm{p}>.05$ ). The correlations indicated that as authoritative parenting style increases, modern sex role ideology also increases. In other words, as one is trained with more authoritative parenting style he or she is more likely to endorse modern sex role ideology. On the other hand, testing for the research question, APS significantly and positively correlated to how students own their learning (OWL $r=0.670^{*} \mathrm{p}<0.05$ ), however with modern sex ideology, there was no significance even though the correlation was positive. Indications are that learners who are trained under authoritative parenting styles tend to own their learning the more when the parenting style strategy is increased.

\section{Regression Analysis}

Multiple regression analysis was conducted in order to ascertain the amount of variance accounted for by the variables entered on the dependent variables and also to determine the extent to which the variables entered predict the dependent variables.

In testing for the hypothesis which predicted that 'authoritative parenting style will significantly predict modern sex role ideology regression analysis using force entry method was performed to assess relative contribution of parenting styles-authoritative in the prediction of sex role ideologies (traditional and modern sex role ideologies) of participants. Table 6 displays unstandardized (B) and Standardized Beta $(\beta)$ regression coefficients, the multiple correlation coefficients (R), adjusted $\mathrm{R}^{2}$, and the value of $(t)$ and its associated p-value for each variable that was entered into the regression equation.

\section{Predictions of Parenting Styles on Traditional Sex Role Ideology}

Results from the forced entry regression analysis of traditional sex role ideology on authoritative parenting style, authoritarian parenting style, and permissive parenting style are shown in the Table 6. 
Amoah, S. A., Owusu-Mensah, F., Gyamera, A., \& Ankama, G. M. (2019). Do Distance Education students owned their learning? Students' perceptions of parenting styles and sex role ideologies. Advances in Social Sciences Research Journal, 6(6) $120-136$.

Table 6: Regression Analysis for parenting styles on Traditional Sex Role Ideology

\begin{tabular}{lllllll}
\hline $\begin{array}{l}\text { Variables } \\
\text { Entered }\end{array}$ & $\mathbf{B}$ & Beta & $\boldsymbol{T}$ & $\mathbf{R}$ & $\mathbf{R}^{\mathbf{2}}$ & Sig. \\
\hline Constant & 24.90 & & 6.56 & & & .000 \\
APS & .083 & .069 & .747 & & & .456 \\
& & & & .203 & .41 & \\
\hline
\end{tabular}

$\mathrm{N}=300$ Source: regression analysis table from SPSS

The forced entry regression analysis of authoritative on traditional sex role ideology was used to test for the predictions of parenting styles on traditional sex role ideology.

As shown in Table 6, authoritative parenting style, explained $41 \%$ (adjusted $\mathrm{R}^{2}=.41$ ) of the variance in traditional sex role ideology. This also suggests that there is about 59\% of the variance that is due to other factors. This suggested that the present variables entered were not good predictors of traditional sex role ideology. As indicated by Table 6, the contributions of authoritative parenting style, to the variance in traditional sex role ideology was not statistically significant $(p>.05)$.

Result from Table 6 suggested that authoritative parenting style was not a significant predictor of traditional sex role ideology $(\beta=.069, t=.747),(p>.05)$. This result does not support the second hypothesis that 'authoritative parenting style would significantly predict more traditional sex role ideology’.

In conclusion, authoritative parenting style constructs contributed to only $41 \%$ of the variance in predicting traditional sex role ideology of the participants and therefore authoritative parenting style is not good predictors of traditional sex role ideology

\section{Predictions of Parenting Styles on Modern Sex Role Ideology}

Table 7, displays unstandardized (B) and Standardized Beta $(\beta)$ regression coefficients, the multiple correlation coefficients (R), adjusted $\mathrm{R} 2$, and the value of $(\mathrm{t})$ and its associated $\mathrm{p}$-value for each variable that was entered into the regression equation.

Results from the forced entry regression analysis of authoritative parenting style on modern sex role ideology is shown in the Table 7.

Table 7: Regression Analysis for parenting styles on Modern Sex Role Ideology

\begin{tabular}{lcccccc}
\hline $\begin{array}{l}\text { Variables } \\
\text { Entered }\end{array}$ & $\mathbf{B}$ & Beta & $\boldsymbol{T}$ & $\mathbf{R}$ & $\mathbf{R}^{\mathbf{2}}$ & Sig. \\
\hline Constant & 29.51 & & 5.72 & & & .000 \\
APS & .252 & .155 & 1.68 & & & .096 \\
MSRI & .152 & .093 & .996 & & & .321 \\
TSRI & .094 & .072 & .768 & .199 & .04 & .444 \\
& & & & .199 & \\
\hline
\end{tabular}

Source: regression analysis from SPSS

The forced entry regression analysis of authoritative, authoritarian and permissive parenting on modern sex role ideology was used to test for the predictions of parenting styles on modern sex role ideology.

As shown in Table 7, authoritative parenting style, explained only $4 \%$ (adjusted $\mathrm{R}^{2}=.04$ ) of the variance in modern sex role ideology. This also suggests that there is about $96 \%$ of the variance that was due to other factors. This suggested that the present variables entered are 
not good predictors of traditional sex role ideology. As indicated by Table 7, the contributions of authoritative parenting style, to the variance in modern sex role ideology were not statistically significant $(p<.05)$ as the minimum $p$ - value to make prediction and only accounted for $4 \%$ of the variance.

Table 7 suggest that authoritative parenting style was not a significant predictor of modern sex role ideology $(\beta=.155, t=1.68),(p>.05)$. This result does not support the second hypothesis that 'authoritative parenting style would significantly predict modern sex role ideology'. The result suggests that authoritative parenting style has no significant contribution on modern sex role ideology of participants.

In sum, the parenting style constructs (authoritative) was found not to be statistically significant predictors of sex role ideologies. In traditional sex role ideology, authoritative parenting styles contributed to only $41 \%$ of the variance in predicting traditional sex role ideology of the participants.

Based on the results shown in Tables 6 and 7, the hypothesis that 'authoritative parenting style would significantly predict modern sex role ideology is rejected. The findings did not support hypothesis two and therefore sex role ideologies (modern and traditional sex role ideologies) were significantly predicted by other variables rather than parenting styles of participants.

Table 8: Regression Analysis for owning learning from parenting styles on Modern Sex Role Ideology and traditional sex role ideology

\begin{tabular}{lcccccc}
\hline Variables & B & Beta & $\boldsymbol{T}$ & $\mathbf{R}$ & $\mathbf{R}^{\mathbf{2}}$ & Sig. \\
Entered & 29.51 & & 5.72 & & & .000 \\
Constant & .252 & .155 & 1.68 & & .096 \\
APS & .152 & .093 & .996 & & .321 \\
MSRI & .094 & .072 & .768 & & & .444 \\
TSRI & .213 & .070 & .712 & & & .041 \\
OWL & & & & .810 & .656 & \\
\hline
\end{tabular}

\section{Source: regression analysis from SPSS}

As shown in Table 8, owning learning was explained 67\% (adjusted $\mathrm{R}^{2}=.656$ ) of the variance in authoritative Parenting styles, modern sex role ideology and traditional sex role ideology. This also suggests that there is about $33 \%$ of the variance that was due to other factors. This suggested that the present variables entered are good predictors of how students own their learning. As indicated by Table 8, the contributions of authoritative parenting style, traditional sex ideology and modern sex ideology to the variance in students owning their learning were statistically significant $(p<.05)$ as the minimum $p-v a l u e$ to make prediction since the variables accounted for $67 \%$ of the variance.

The result suggests that authoritative parenting style, traditional sex role ideology and modern sex role ideology all contributed to how students own their learning. In sum, based on the results shown in Tables 8 the research question, what extent does parenting styles, sex role ideologies support DE students learn to own their learning? Parenting styles and sex role ideologies support students of DE own their learning

\section{DISCUSSION OF RESULTS}

This study was aimed at examining the relationship between students' perception of parenting styles and sex role ideologies. In addition it sought to look at how these relationships influence how they learn. The study also sought to examine how the parenting styles affected or 
predicted the sex role ideologies of the respondents, in addition to these constructs support learners to own their learning.

It was hypothesised by the researcher that 'there will be a statistically significant relationship between authoritarian parenting style and traditional sex role ideology of Distance Education students from treh University of Education, Winneba. This hypothesis was also backed by findings from studies by (Park \& Bauer, 2002; Steinberg, Elman, \& Mounts, 1989; Leung, Lau, \& Lam, 1998; Chen, Dong, \& Zhou, 1997; and Dornbusch et. al., 1987) which found authoritarian parenting style significantly correlate opposite to authoritative parenting style. However, these studies have found academic achievement, social competence and other aspect of children behaviour to be negatively correlated with authoritarianism. For instance Leung, Lau, and Lam (1998), and Dornbusch et. al. (1987) found out that academic achievement was negatively correlated with authoritarianism.

Finally, it was also hypothesised that authoritative parenting style will significantly predict modern sex role ideology, DE students. This hypothesis was also based on previous findings from studies by Baumrind (1991), Kokpo (2007), and Ngwiri (2008) which have all consistently found authoritative parenting style as a predictor of children well-being in the domains of academic performance, psychological development, cognition and social competence. Besides, how DE students own their learning has been found to depend on the parenting and sex role ideologies which could not be confirmed by issues raised by Ankama, 2017 and Owusu-Mensah, 2018..

\section{Conclusion}

\section{SUMMARY, IMPLICATIONS, AND CONCLUSION}

This study was conceived based on the researchers' ontological and epistemological position that there is natural fact that parenting styles, sex role ideologies have some relationships with how students own their learning and therefore the researchers tried to use objective scientific approach and theories to discover this natural knowledge using the researchers' position on positivist realism and positivist objectivism on the relationship between the variableconstructs used in the study.

Based on this position, the researchers were of the view that parenting styles would correlate and influence sex role ideologies of the participants, in addition to how students own their learning.

The conclusion from the findings of this study is that as an individual is trained with authoritative parenting style with identified sex role ideology, there is a higher tendency that DE learners can own their learning.

\section{Implications and Recommendations of the study}

The findings of this study indicated that students' perception of parenting styles relates to their sex role ideology especially authoritative therefore parents who are more egalitarian in sex role ideology should try as much as possible to train their wards to own their learning.

Parents should also be aware that in order to train their children to have or form equal or same parenting style as well as sex role ideology, they should refrain from training their children with different roles according to their sex in order for the children to own their learning. 


\section{SUGGESTIONS FOR FURTHER STUDIES}

Based on the conclusions of the study, the following recommendation is made for future studies;

Variables such as beliefs and perceptions are greatly influenced by culture and for that matter what is perceived in Western or European culture may be different in Ghana or Africa, hence indepth studies need to be conducted unravel how these beliefs can support learners own their learning.

\section{References}

Abell, E., Clawson, M., Washington, W. N., Bost, K. K., \& Vaughn, B. E. (1996). Parenting values, attitudes, behaviours, and goals of African American mothers from a low-income population in relation to social and societal contexts. Journal of Family Issues, 17, 593-613.

Ampofo, A. A. (2001). When men speak women listen: Gender socialisation and young adolescents' attitudes to sexual and reproductive issues. African Journal of Reproductive Health. 5(3), 196-212.

Akinade, E. A., \& Owolabi, T. (2010). Research methods: A pragmatic approach for social sciences, behavioural sciences and education. Lagos: Connel Publications.

Akotia, C. S., \& Anum, A. (2012). The moderating effects of age and education on gender differences on gender role perceptions. Gender and Behaviour, 10(2), 5022-5043.

Amoah, E. (1991). Femaleness, Akan concepts and practices. In J. Becher (Ed.) Women, religion and sexuality, studies on the impact of religious teachings on women. Philadelphia: Trinity Press Int.

Arnold, A. P. (2010). Promoting the understanding of sex differences to enhance equity and excellence in biomedical science. Biology of Sex Differences, 1(1), 1-3.

Bandura, A. (2002). Social cognitive theory in cultural context. Applied Psychology, 51(2), 269-290.

Barry, D. T. \& Beitel, M. (2006). Sex role ideology among East Asian immigrants in the United States. American journal of Orthopsychiatry, 76, 512-517.

Bem, S., (1981). Gender schema theory: A cognitive account of sex-typing. Psychological Review, 88.

Berk, L.E., (2000). Child Development, 5th Edition. Needham Heights: Allyn \& Bacon Press.

Bornstein, M., (2002). A Handbook of parenting. Mahwah, NJ: Lawrence Erlbaum.

Boveja, M. E. (1998). Parenting styles and adolescents' learning strategies in the urban community. Journal of Multicultural Counseling and Development, 26, 110-119.

Brewster, K., \& Padavic, I. (2000). Change in gender ideology, 1977-1996: The contributions of intra cohort change and population turnover. Journal of Marriage and the Family, 62, 477-487.

Buri, J. (1991). Parental authority questionnaire. Journal of Personality Assessment, 57(1), 110-119.

Chao, R. (2000). The parenting of immigrant Chinese and European American mothers: Relations between parenting styles, socialization goals, and parental practices. Journal of Applied Developmental Psychology, 21(2), 233-248.

Chang, L. (1999). Gender egalitarian attitudes in Beijing, Hong Kong, Florida and Michigan. Journal of CrossCultural Psychology, 30, 722-742.

Chen, X., Dong, Q., \& Zhou, H. (1997). Authoritative and authoritarian parenting practices and social and school performance in Chinese children. International Journal of Behavioural Development, 21(4), 855-873.

Cherry, K., (2010). Parenting styles: the four styles of parenting. Applied Psychology, 51(3), 260-290.

Dalton, W., Frick-Horbury, D., \& Kitzmann, K. (2006). Young adults' retrospective reports of parenting by mothers and fathers: Associations with current relationship quality. Journal of General Psychology, 133(1), 5-18.

Darling, N. (2001). Parenting style and its correlates. Psychological bulletin, 223(4), 487.

Dewar, G. (2010). Parenting Styles: A Guide for the science-minded. Applied Psychology. 51(2), 269-290.

Diekman, A. B., Goodfriend, W., \& Goodwin, S. (2004). Dynamic stereotypes of power: Perceived change and stability in gender hierarchies. Sex Roles. 50(4), 201-215. 
Amoah, S. A., Owusu-Mensah, F., Gyamera, A., \& Ankama, G. M. (2019). Do Distance Education students owned their learning? Students' perceptions of parenting styles and sex role ideologies. Advances in Social Sciences Research Journal, 6(6) $120-136$.

Dornbusch, S. M., Ritter, P. L., Leiderman, P. H., \& Roberts, D. F. (1987). The relation of parenting style to adolescent school performance. Child Development, 58, 1244-1257.

Dornbusch, S., Glasgow, K, Ritter, P. L., Steinberg, L., \& Troyer, D. (1997). Parenting styles, adolescents attributions, and educational outcomes in nine heterogeneous high schools. Child development vol. 2, 507 - 529.

Eagly, A. H. (1987). Sex Differences in Social Behaviour: A Social-Role Interpretation. Hillsdale, NJ: Lawrence Erlbaum Associates, Inc.

Eagly, A. H. Steffen, V.J. (1984). Gender stereotypes stem from the distribution of women and men into social roles. Journal of Personality and Social Psychology. 46 (4), 735-754.

Eagly, A. H. \& Wood, W. (1991). Explaining sex differences in social behaviour: a meta-analytical perspective. Personality and Social Psychology Bulletin. 17, 306-315.

Eagly, A. H., Karau, S. J., \& Makhijani, M. G. (1995). Gender and the effectiveness of leaders: a meta-analysis. Psychological bulletin, 117(1), 125.

Eagly, A. H., Wood, W., \& Diekman, A. B. (2000). Social role theory of sex differences and similarities: A current appraisal. The Developmental Social Psychology of Gender. 123-174.

Etchezahar, E., \& Ungaretti, J. (2013). Women stereotypes and ambivalent sexism in a sample of adolescents from Buenos Aires. Journal of Behaviour, Health and Social Issues. Vol. 6, 87 - 94.

Folbre, N., Christensen, K., Gringeri, C., Matthaei, J., Kornbluh, F., Rose, N. (2001). The Invisible Heart: Economics and Family Values. LA: Sage

Gerson, K. (2002). Moral dilemmas, moral strategies, and the transformation of gender lessons from two generations of work and family change. Gender \& Society, 16(1), 8-28.

Greenwood, B. (2014). The Baumrind theory of parenting Styles. Applied Psychology, 55(2).

Hart, C. H., Mandleco, B., Olson, S. F., \& Robinson, C. C. (1998). Authoritative, authoritarian, and permissive parenting practices: Development of a new measure. Journal of Psychological Reports, 77, 819-830.

Heilman, M. E., Wallen, A. S., Fuchs, D. \& Tamkins, M. M. (2004). Penalties for success: Reactions to women who succeed at male gender-typed tasks. Journal of Applied Psychology, 89, 416-427.

Helgerson, S. V. (2009). The Psychology of Gender (3rd. Ed.).Upper Saddle River NJ. Prentice Hall.

Helmreich, R. L., Spence, J. T., \& Gibson, R. H. (1982). Sex-role attitudes: 1972-1980. Personality and Social Psychology Bulletin, 8(4), 656-663.

Hill, N. E. (1995). The relationship between family environment and parenting style: A preliminary study of African American families. Journal of Black Psychology, 21, 408-423.

Hochschild A, (2003). The second shift: Family \& Society Studies Worldwide, Ipswich, MA.

Hoffman, E., (2000). German family structures and parenting practices. Paper presented at German family organization forum. Munich. Journal of Family Issues, 16(5), 34-58.

Hoghughi, M. S., \& Long, N. (Eds.). (2004). Handbook of parenting: theory and research for practice. LA: Sage Publications.

Hyde, L. (1993). Social Role Theory. Annual Review of Sex Research, 10(1), 70-99.

Keller, H. \& Otto, H. (2009). The cultural socialization of emotion regulation during infancy. Journal of CrossCultural Psychology, 40 (6), 996-1011.

Konrad, A. M., Ritchie Jr, J. E., Lieb, P., \& Corrigall, E. (2000). Sex differences and similarities in job attribute preferences: a meta-analysis. Psychological Bulletin, 126(4), 593.

Kopko, K., (2007). Parenting styles and adolescents. Cornell Cooperative Extension: Cornell University, U.S.A.

Krejcie, R.V. \& Morgan, D.W. 1970. Determining sample size for research activities. Educational and Psychological Measurement. 30.607-610.

Kroska, A. (2014). The Social Psychology of Gender Inequality. Netherlands: Springer.

Kulik, L. (2002). The impact of social background on gender-role ideology parents' versus children's attitudes. Journal of Family Issues, 23(1), 53-73.

Kusi, H. (2012). Qualitative Research: A guide for researchers. Accra New Town: Accra, Emmpong Presss. 
Lamborn, S.D., Mounts, N.S, Steinberg, L., \& Dornbusch, S.M. (1991). Patterns of competence and adjustment among adolescents from authoritative, authoritarian, indulgent, and neglectful families. Child Development, 62 (5), 1049-1065

Leung, K., Lau, S., \& Lam, W. L. (1998). Parenting styles and academic achievement: A cross-cultural study. MerrillPalmer Quarterly (1982-), 157-172.

Maslak, M. A., \& Singhal, G. (2008). The identity of educated women in India: confluence or divergence? Gender and Education, 20(5), 481-493.

McBroom, W. H. (1987). Longitudinal change in sex role orientations: difference s between men and women. Journal of Sex Roles, 16, 439-452.

McHugh, M. C., \& Frieze, I. H. (1997). The measurement of gender-role attitudes: A review and commentary. Psychology of Women Quarterly, 21, 1-16.

Meredith, A. S. (2009). Gender differences in Parenting Styles and Child relationship. San Marcos: Texas

Moss, P. (2008). Beyond quality in early childhood education and care-language of evaluation. New Zealand Journal of Teachers' work. Vol. 5(1), 03 - 12.

Moya, M., \& Exposito, F. (2001). Roles and women's well-being: Some preliminary findings from Malaysia. Journal of Sex Roles, 41, 123-145.

Myer, S., \& Both, A. (2002). Forerunners of change in non-traditional gender ideology. Social Psychology Quarterly, 65, 18-37.

Myranda,G.,(2013). Gender roles and ideology: Crossing the divide. Journal of Sex Roles, 64, 453-469.

Nukunya, G. K. (2003). Tradition and Change in Ghana. An introduction to sociology. (2ndEd.). Accra: Ghana Universities Press.

Opia, M. K. (2010). Changing man attitude: Studies in family planning. Journal of Family Psychology, 22(4), 68.

Owano, D. A., (2010). Perception of secondary school students on effects of parenting styles on their academic performance: A case study of Bongo District, Kenya. Kenya: Egerton University.

Park, B. \& Bauer, S. (2002). Correspondence between maternal and paternal parenting style. Child development.65(6), 142-156.

Radziszewska, B., Richardson, J. L., Dent, C. W., \& Flay, B. R. (1996). Parenting style and adolescent depressive symptoms, smoking, and academic achievement: Ethnic, gender, and Sex differences. Journal of Behavioural Medicine, 19(3), 289-305.

Ribeiro, L. L., (2009). Construction and validation of a four parenting style scale. California, Arcata: Humboldt State University

Rice, T. W., \& Coates, D. L. (1995). Gender role attitudes in the southern United States. Gender \& Society, 9(6), 744756.

Robison-Awana, P., Kehle, T. J., \& Jenson, W. R. (1986). But what about smart girls? Adolescent self-esteem and sex role perceptions as a function of academic achievement. Journal of Educational Psychology, 78(3), 179.

Rocha-Sánchez, T., \& Díaz-Loving, R. (2005). Gender and the social rights of citizenship: The comparative analysis of gender relations and welfare states. American Sociological Review, 58(3), 303-328.

Roopnarine, J. L., Talukder, E., Jain, D., Joshi, P., \& Srivastav, P. (1990). Characteristics of holding, patterns of play, and social behaviours between parents and infants in New Delhi, India. Developmental Psychology, 26(4), 667.

Rothbaum, F., \& Trommsdorff, G. (2007). Do roots and wings complement or oppose on another: The socialization of relatedness and autonomy in cultural context. New York: Guilford press.

Sefa-Dedeh, A., \& Canetto, S. S. (1992). Women, family and suicidal behaviour in Ghana. Journal of Family Issues, 16(5), 383-402.

Slavkin, M., \& Stright, A. D. (2000). Gender role differences in college students from one- and two-parent families. Journal of Sex Roles, 42(2), 23-37.

Steinberg, L., Mounts, S. N. \& Elman, D J., (1989). Authoritative parenting, psychosocial Maturity and academic success among adolescents. Journal of society for research in child development.20(5), 566-598.

Swim, J. K., Aikin, K. J., Hall, W. S., \& Hunter, B. A. (1995). Sexism and racism: Old-fashioned and modern prejudices. Journal of Personality and Social Psychology, 68(2), 199. 
Amoah, S. A., Owusu-Mensah, F., Gyamera, A., \& Ankama, G. M. (2019). Do Distance Education students owned their learning? Students' perceptions of parenting styles and sex role ideologies. Advances in Social Sciences Research Journal, 6(6) $120-136$.

Tougas, F., Brown, R., Beaton, A. M., \& Joly, S. (1995). Neosexism. Personality and social psychology bulletin, 21(8), 842-849.

Wiley, M. G., \& Eskilson, A. (1985). Speech style, gender stereotypes, and corporate success: What if women talk more like men? Sex Roles, 12, 993-1007.

Wilkie, J. R. (1993). Changes in US men's attitudes toward the family provider role, 1972-1989. Gender \& Society, $7(2), 261-279$.

Williams, J. E., \& Best, D. L. (1990). Sex and psyche: Gender and self-viewed cross-culturally. LA: Sage Publications.

Williams, J. E., \& Best, D. L. (1982). Measuring sex stereotypes: A thirty-nation study. Beverly Hills, CA: Sage. 